Transitional Justice 
Genocide, Political Violence, Human Rights Series

Edited by Alexander Laban Hinton, Stephen Eric Bronner, and Nela Navarro 


\section{Transitional Justice}

Global Mechanisms and Local Realities after Genocide and Mass Violence

EDITED BY

ALEXANDER LABAN HINTON

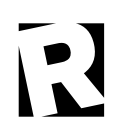

RUTGERS UNIVERSITY PRESS

NEW BRUNSWICK, NEW JERSEY, AND LONDON 
First paperback printing, 20 I I

\section{LIBRARY OF CONGRESS CATALOGING-IN-PUBLICATION DATA}

Transitional justice : global mechanisms and local realities after genocide and mass violence / edited by Alexander Laban Hinton.

p. cm. - (Genocide, political violence, human rights)

Based on a conference held in 2007 in Newark, N.J.

Includes bibliographical references and index.

ISBN 978-o-8I35-5068-8 (pbk. : alk. paper)

ISBN 978-o-8I35-476I-9 (hardcover : alk. paper)

I. Transitional justice. 2. Crimes against humanity. I. Hinton, Alexander Laban. JC57I.T6994 2010

364.I5'I-dc22

2009036232

A British Cataloging-in-Publication record for this book is available from the British Library.

A version of "(In)Justice: Truth, Reconciliation, and Revenge in Rwanda's Gacaca" by Jennie E. Burnet was previously published as "The Injustice of Local Justice: Truth, Reconciliation, and Revenge in Rwanda” in Genocide Studies and Prevention 3, no. 2 (2008): I73-I93. Reprinted with permission of the journal editors.

This collection copyright (C) 2010 by Rutgers, The State University

Individual chapters copyright (c) 2010 in the names of their authors

All rights reserved

No part of this book may be reproduced or utilized in any form or by any means, electronic or mechanical, or by any information storage and retrieval system, without written permission from the publisher. Please contact Rutgers University Press, Ioo Joyce Kilmer Avenue, Piscataway, NJ 08854-8099. The only exception to this prohibition is "fair use" as defined by U.S. copyright law.

Visit our Web site: http://rutgerspress.rutgers.edu

Manufactured in the United States of America 